\title{
Spatially Resolved U(VI) Partitioning and Speciation: Implications for Plume Scale Behavior of Contaminant $U$ in the Hanford Vadose Zone
}

Jiamin Wan ${ }^{1 *}$, Yongman Kim ${ }^{1}$, Tetsu K. Tokunaga ${ }^{1}$, Zheming Wang $^{2}$, Suvasis Dixit ${ }^{1}$, Carl I. Steefel ${ }^{1}$, Eduardo Saiz ${ }^{3}$, Martin Kunz ${ }^{4}$, Nobumichi Tamura ${ }^{4}$

*Corresponding author phone: (510) 486-6004; email: jwan@lbl.gov.

1. Earth Sciences Division, Lawrence Berkeley National Laboratory

2. Pacific Northwest National Laboratory, Richland, WA

3. Material Science Division, Lawrence Berkeley National Laboratory

4. Advanced Light Source (ALS), Lawrence Berkeley National Laboratory

ABSTRACT A saline-alkaline brine containing high concentrations of U(VI) was accidentally spilled at the Hanford Site in 1951, introducing 10 tons of U into sediments under storage tank BX-102. U concentrations in the deep vadose zone and groundwater plumes increase with time, yet how the $\mathrm{U}$ has been migrating is not fully understood. We simulated the spill event in laboratory soil columns, followed by aging, and obtained spatially resolved $\mathrm{U}$ partitioning and speciation along simulated plumes. We found after aging, at apparent steady state, that the pore aqueous phase $U$ concentrations remained surprisingly high (up to $0.022 \mathrm{M}$ ), in close agreement with the recently reported high $\mathrm{U}$ concentrations (up to $0.027 \mathrm{M}$ ) in the vadose zone plume (1). The $\mathrm{pH}$ values of aged pore liquids varying from 10 to 7 , consistent with the measured $\mathrm{pH}$ of the field borehole sediments varying from 9.5 to 7.4 (2), from near the plume source to the plume front. The direct measurements of aged pore liquids together with thermodynamic calculations using 
a Pitzer approach revealed that $\mathrm{UO}_{2}\left(\mathrm{CO}_{3}\right)_{3}{ }^{4-}$ is the dominant aqueous $\mathrm{U}$ species within the plume body ( $\mathrm{pH} 8-10)$, while $\mathrm{Ca}_{2} \mathrm{UO}_{2}\left(\mathrm{CO}_{3}\right)_{3}$ and $\mathrm{CaUO}_{2}\left(\mathrm{CO}_{3}\right)_{3}{ }^{2-}$ are also significant in the plume front vicinity ( $\mathrm{pH} 7-8)$, consistent with that measured from field borehole porewaters (3). U solid phase speciation varies at different locations along the plume flow path and even within single sediment grains, because of location dependent pore and micropore solution chemistry. Our results suggest that high geochemical stability of $\mathrm{UO}_{2}\left(\mathrm{CO}_{3}\right)_{3}{ }^{4-}$ in the original carbonate and sodium rich waste solution permits its continues migration and the field observed increases of $U$ concentrations in the vadose zone and groundwater.

\section{Introduction}

The Hanford Site is one of the DOE's largest contaminated nuclear weapons production legacy sites, located in a semiarid area of south central Washington State that discharges groundwater into the Columbia River (4). U, together with other contaminants was released to the Hanford vadose zone through leakage of massive underground storage tanks containing concentrated high level radioactive wastes, and through discharges of lower concentration wastewaters into retention basins, cribs, and trenches. The B-BX-BY tank farm complex located in the 200 East Area of Hanford Site was used to store waste solutions from the plutonium-uranium plant. The Tank BX-102 overfilling in 1951 was the largest single accident in Hanford's history and left an estimated 10,000 $\mathrm{kg}$ of $\mathrm{U}(\mathrm{VI})$ in the deep vadose zone (5). A U plume was identified in groundwater (Figure 1) (the water table is at $\sim 80 \mathrm{~m}$ depth) with increased concentrations over time, and the source was traced to the BX-102 1951 spill $(6,7)$. A comprehensive 
understanding of spatial distribution, speciation and migration of the contaminant $U$ is extremely difficult to obtain because of the unknown history of the infiltration rates and paths of the waste-liquid and its interactions with sediment. Figure 1 illustrates the layout of B-BX-BY tank farms, spilled tank BX-102, its associated vadose zone and groundwater plumes, as well as two boreholes referred to in later sections. Direct characterizations of the core sediment from borehole 299-E33-45 have provided valuable information about the waste plume (2), and selected results (discussed further in later sections) are shown in Figure 2. Microscopic and spectroscopic studies of selected samples from this borehole identified uranyl silicate (uranophane) as the dominant $U$ species, residing within micro fractures of feldspar grains (9-13). Column and batch experiments using contaminated sediments from this borehole indicated that slow dissolution kinetics of the U(VI) silicates and intragranular mass transfer are expected to keep rates of $\mathrm{U}(\mathrm{VI})$ release into pore waters low (14). Laser fluorescence spectroscopy studies of the borehole samples identified $\mathrm{UO}_{2}\left(\mathrm{CO}_{3}\right)_{3}{ }^{4-}$ and $\mathrm{Ca}_{2} \mathrm{UO}_{2}\left(\mathrm{CO}_{3}\right)_{3}$ as the predominant U species in the plume aqueous phase (3). Significant progress has been made in understanding the $\mathrm{U}$ residing under the tank BX-102, as summarized in Zachara et al. (4).

A recent report (1) showed very high U concentrations detected at depth around 7075 meters (gamma spectral logging, just above the water table) from the monitoring borehole 299-E33-18 (Figure 3), believed to originate from the BX-102 overfill event. The measured maximum ${ }^{238} \mathrm{U}$ activity was surprisingly high as $1237 \mathrm{pCi} \mathrm{g}^{-1}$, equivalent to $\mathrm{U}$ pore water concentration $0.027 \mathrm{M}(34 \%$ water saturation, measured using neutron density logging at the same location). These newly obtained field measurements raised 
the question of how it was possible for such high $U$ concentrations to exist in mobile pore liquids a half-century after the spill. Our study is intended to help answer this question. Taking a different approach, we simulated the tank BX-102 overfilling event in laboratory columns. The results are presented in two papers. In the earlier paper (15), we reported that the infiltration rate of the original waste liquid and hydraulic conductivity of the sediment controlled $U$ partitioning and spatial distribution. $U$ was practically unretarded at flow rates $>5 \mathrm{~cm} \mathrm{day}^{-1}$. Given the very high hydraulic conductivity of Hanford formation sands $\left(10^{2}\right.$ to $\left.10^{4} \mathrm{~m} \mathrm{day}^{-1}\right)$, only the low permeability zones/layers within the sediments are responsible for retaining significant $U$ in Hanford vadose zone when the leakage rate is high. In this paper we present spatially resolved $U$ partitioning and speciation along the simulated $U$ plumes after aging. 


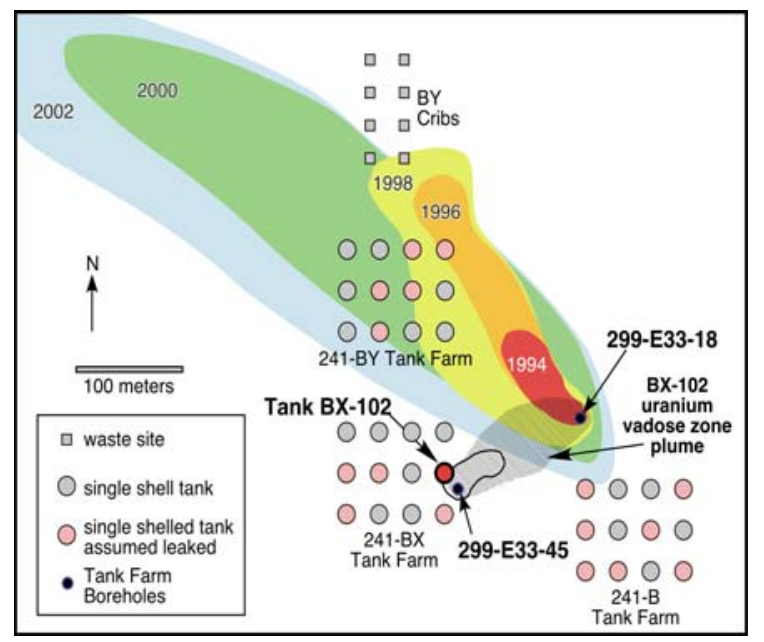

Figure 1. Schematic layout of B-BX-BY tank farms, spilled tank BX-102, its associated vadose zone plume, groundwater plume, two tank farm boreholes 299-E33-45 and 299E33-18. Borehole 299-E33-45 provided contaminated sediment for investigations, and borehole 299-E33-18 served as a monitoring well ( $\sim 140$ meters NE of tank BX-102). Groundwater plume extents estimated for $20 \mu \mathrm{g} \mathrm{L} \mathrm{L}^{-1}(0.084 \mu \mathrm{M}) \mathrm{U}$ every other year from 1994 to 2002. (Redrawn from RPP-10098, 2003 (8)) 


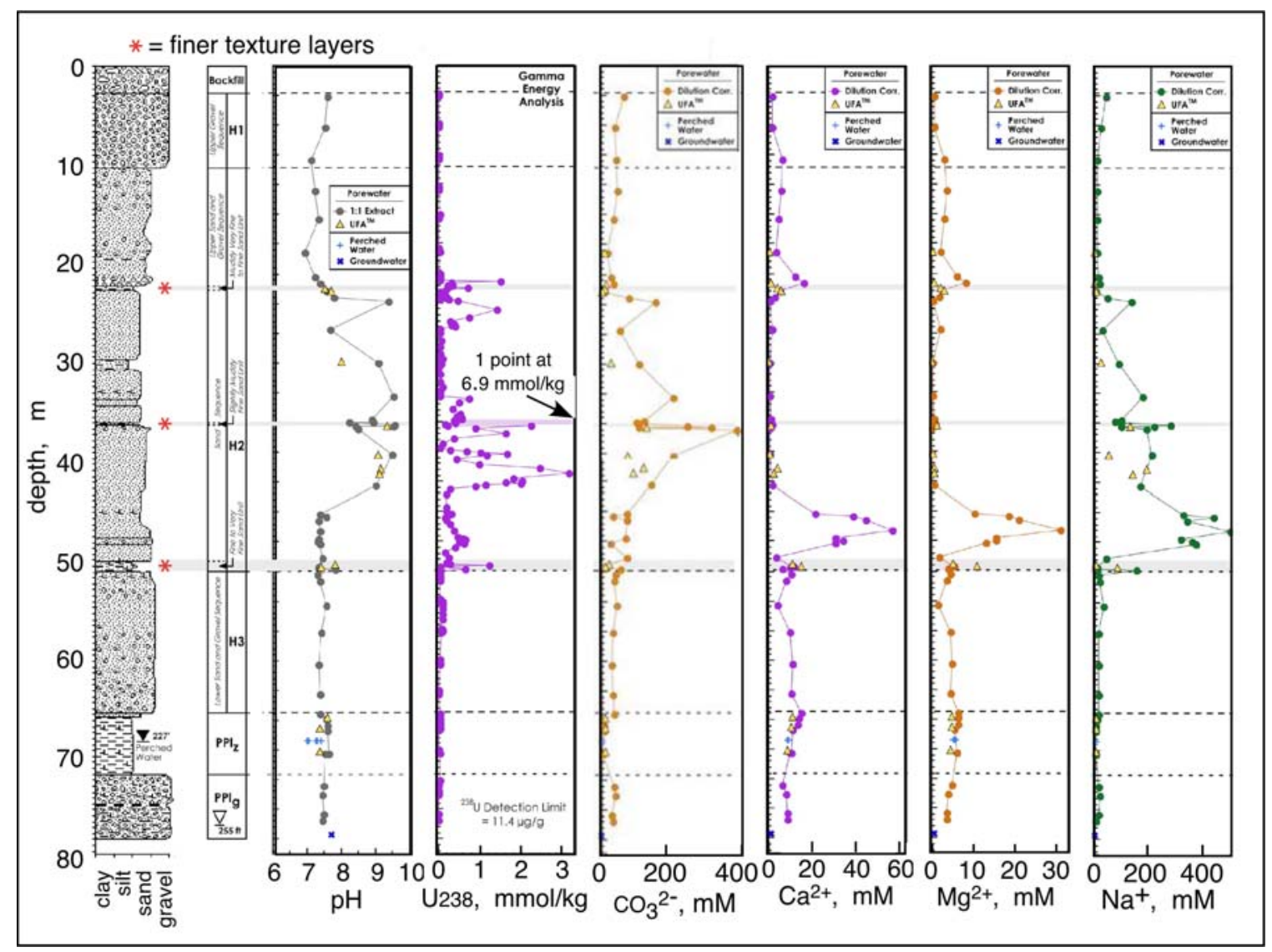

Figure 2. Schematic lithology profile of borehole 299-E33-45, showing gravel and sand dominated Hanford Formation sediment with fine-grained (clay-rich) intervals, and profiles of selected geochemical components. The $\mathrm{pH}, \mathrm{Na}^{+}, \mathrm{Ca}^{2+}, \mathrm{Mg}^{2+}$, and $\mathrm{HCO}_{3}{ }^{-}$ profiles were from 1:1 water:sediment extracts, and $U$ profile was by gamma ray logging. The elevated concentrations of $\mathrm{U}, \mathrm{Na}^{+}, \mathrm{Ca}^{2+}, \mathrm{Mg}^{2+}$, and $\mathrm{HCO}_{3}^{-}$suggest the borehole intersects with a plume front region at the depths $45-51 \mathrm{~m}$, where $\mathrm{pH}$ values are neutral, but indeed is a part of the plume. (Modified from Serne et al., 2002 (2)). 


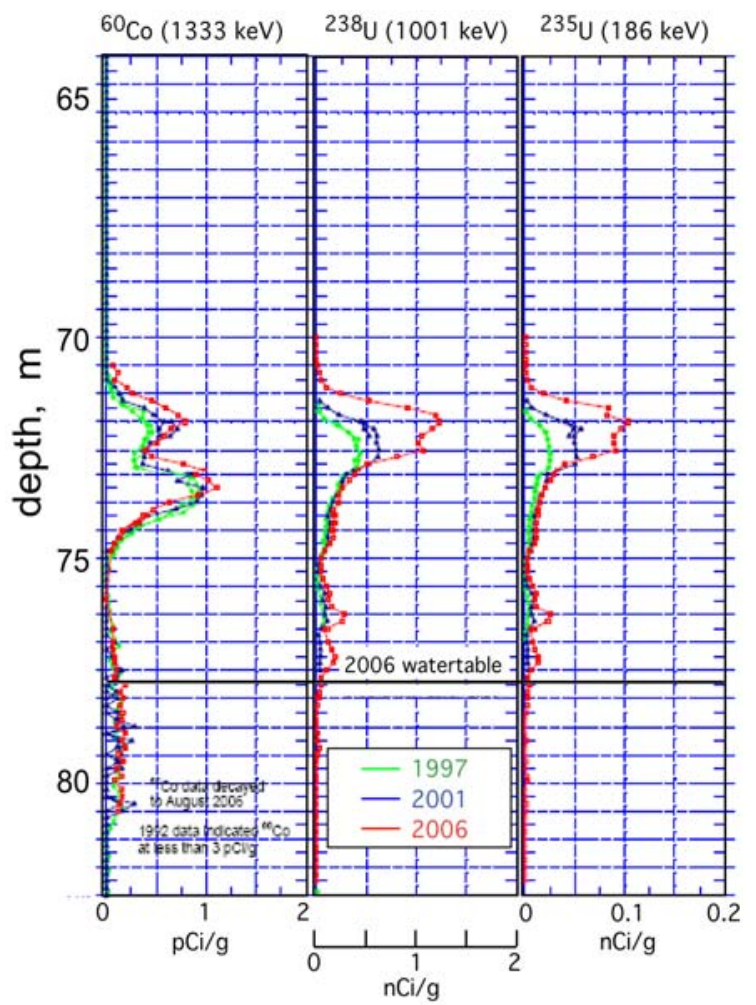

Figure 3. Uranium and cobalt concentration profiles (spectral gamma logging) along monitoring well 299-E33-18, showing U and Co concentrations increased over time (no contaminants were detected in 1992 logging). The measured maximum ${ }^{238} \mathrm{U}$ activity reached to $1.24 \mathrm{nCi} \mathrm{g}^{-1}$, equivalent to $\mathrm{U}$ pore water concentration $0.027 \mathrm{M}(34 \%$ water saturation, measured using neutron density logging at the same location). (From McCain, $2006(1))$ 


\section{Experiment Methods and Material}

Metal Waste Solution (MWS). The reported tank waste solution at the time of spill contained 0.114 to $0.122 \mathrm{M} \mathrm{U}(\mathrm{VI}), 2.1$ to $2.92 \mathrm{M}$ sodium, 0.61 to $0.64 \mathrm{M}$ total carbonate from two different reports $(5,16), 0.53 \mathrm{M}$ nitrate, $0.36 \mathrm{M}$ phosphate, and $0.23 \mathrm{M}$ sulfate, and had $\mathrm{pH} 10.4(5,16)$. We synthesized the waste solution based on the historical $\mathrm{Pu}$ extraction procedure of Serne et al. (17) to obtain partitioning of $U$ between sludge and supernatant while excluding the fission products. The detailed steps were presented in Wan et al. 2008 (15). Our synthesized solution contained the following measured concentrations; $0.114 \mathrm{M} \mathrm{U}, 0.75 \mathrm{M}$ total $\mathrm{C}, 0.34 \mathrm{M} \mathrm{P}, 0.24 \mathrm{M} \mathrm{SO}_{4}{ }^{2-}, 0.87 \mathrm{M} \mathrm{NO}_{3}{ }^{-}$, and 3.4 $\mathrm{M} \mathrm{Na}^{+}$, and had a $\mathrm{pH}$ of 10.4. The total analyzed anion versus cation charge concentrations are $-3.1 \mathrm{M}_{\mathrm{c}}$ and $+3.4 \mathrm{M}_{\mathrm{c}}$, respectively without accounting for the effect of high ionic strength on $\mathrm{pK}_{\mathrm{a}}$ values of carbonate and phosphate. The synthesized MWS was stable at both room temperature and $70^{\circ} \mathrm{C}$ over the tested one-year period of time.

Sediment. The sediment used to pack the columns was Hanford formation glaciofluvial sediment collected from the vadose zone in the 200 East Area at a depth of about 1.5 to 3 m. Its major components are feldspar, quartz, and basaltic rock fragments (15). The sediment used in this study contains $93 \%$ sand, $6.0 \%$ silt, and $1.0 \%$ clay. Calcium carbonate comprises $1.1 \%$ of the total mass. The median grain-size is $350 \mu \mathrm{m}$, and average grain density is $2.77 \mathrm{Mg} \mathrm{m}^{-3}$. A water extract from the sediment (water to soil mass ratio $=1: 1$, at $21^{\circ} \mathrm{C}$ for 24 hours) has a $\mathrm{pH} 8.4, \mathrm{Na}^{+} 0.89 \mathrm{mM}, \mathrm{K}^{+} 0.17 \mathrm{mM}, \mathrm{Mg}^{2+}$ $0.11 \mathrm{mM}, \mathrm{Ca}^{2+} 0.23 \mathrm{mM}, \mathrm{Cl}^{-} 0.27 \mathrm{mM}, \mathrm{SO}^{2-} 0.56 \mathrm{mM}$, and $\mathrm{HCO}_{3}^{-} 0.91 \mathrm{mM}$. 
Column Profiling Method. The profiling method employed in this study was developed in our earlier work with column lengths up to 2.0 meter (18-20). In this study, columns were $0.5 \mathrm{~m}$ long and $0.038 \mathrm{~m}$ ID. Uncontaminated Hanford formation sediment with a controlled moisture content of 7.0 mass $\%$ was used to pack the columns. The columns were packed as homogeneously as possible with a typical dry bulk density $\approx 1.65 \mathrm{~g} \mathrm{~cm}^{-3}$. The columns were set vertically in hot-water baths at $70^{\circ} \mathrm{C}$ (the approximate temperature during infiltration of the radioactive waste liquid). The synthetic waste solution was injected into the columns at a pore water velocity $5 \mathrm{~cm} \mathrm{day}^{-1}$. Direct information on the flow rate of the waste liquid during spill was not available, but would have depended in detail on the spill rate and the sediment hydraulic conductivity. Since permeability at the field scale in Hanford formation sands can be highly variable, a flow rate of $5 \mathrm{~cm} \mathrm{day}^{-1}$ was used to represent the likely slower range of those possible. The flow direction was upward to avoid gravity-induced finger flow. Flow was terminated when the calculated infiltration distance reached $30 \mathrm{~cm}$ ( 6 days), thus traversing $60 \%$ of the $50 \mathrm{~cm}$ column. At this stage, each $50 \mathrm{~cm}$ column contained an approximately $30 \mathrm{~cm}$ long simulated waste plume, with about $20 \mathrm{~cm}$ of displaced native soil water. The columns were immediately sectioned $(2.5 \mathrm{~cm}$ each) to obtain chemical profiles. For the control column (aging time zero), the pore liquid from each segment of sediment was immediately extracted using vacuum-filtration through a $2 \mu \mathrm{m}$ filter. The $2 \mu \mathrm{m}$ pore size cellulose filter paper was selected because it permitted rapid filtration. The extracted liquid was prepared for measuring its $\mathrm{pH}$, electrical conductivity, turbidity, major ion chemistry, U concentrations, and determination of $\mathrm{U}$ species. After the pore liquid extraction, the segment sediment was rinsed with $20 \mathrm{ml}$ distilled water and drained through the vacuum 
filter to remove the solutes within the residual pore liquid. This procedure of removing residual pore liquid was done as quickly as possible and usually took about 2 minutes. The washed sediment segments were then air-dried and analyzed for the amount of $U$ retained. The washed sediment was also used later for determining $U$ solid phase speciation. These spatially resolved chemical and physical data allowed us to construct profiles of the plume physical and chemical properties along a flow path.

Aging Experiments. The aging experiments were designed to determine changes in $\mathrm{U}$ partitioning and chemical and mineralogical speciation over time in the absence of continued flow. Four columns were used for 3 time points of aging, 0, 3 and 12 months at $70^{\circ} \mathrm{C}$, with a duplicate run for the 12 month case. The choice of 12 months as the upper time limit was based on our previous results (18) that rapid changes of pore solution chemistry occurred during the first 30 days, and much slower changes thereafter. All the experimental conditions were kept as consistent as possible for all four columns in conducting MWS infiltration. After the infiltration, each column was sectioned, and each segment (containing both pore liquid and sediment) was transferred into a Teflon tube. The choice of aging the sectioned segments instead of whole intact columns was based on the knowledge from our previous study (15) that plume chemistry is highly heterogeneous along the flow path, and that mixing/mass transfer induced by advection and diffusion during aging would be amplified at the laboratory scale compared to the field scale. Each tube therefore contained a segment of the plume and was sealed and weighed to monitor the moisture loss at later times during aging. The tubes were held vertically in a rack within a water-bath at $70^{\circ} \mathrm{C}$, and were open to the atmosphere once a 
week for 10 minutes to approach equilibrium with the atmospheric $\mathrm{P}\left(\mathrm{CO}_{2}\right)$ (the expected condition for coarse-grained, semi-arid vadose zone sediments). Drops of distilled water were periodically added into samples to make up any evaporative weight loss. After the desired aging times ( 3 and 12 months) the same protocol described in the previous section was followed.

Analytical Methods. U concentrations in pore liquids were determined using a kinetic phosphorescence analyzer (KPA, Chemchek, Richland, WA). Major element compositions were determined using ICP (Perkin Elmer 5300, Waltham, MA). Carbon was analyzed using a TIC-TOC analyzer (O-I Analytical). U contents in the segmented sediment samples were measured using gamma spectrometry (GMX-50220-P, E.G.\&G. Ortec, Oak Ridge, TN). Aqueous $\mathrm{U}$ species in the pore fluid were determined using timeresolved laser fluorescence spectroscopy (TRLFS) (21). SEM/EDS was used for characterizing morphology and chemical composition of the sediment associated $U$ species. Synchrotron based micro-XRD was used to determine the mineralogy of Ucontaining solid phase.

Thermodynamic Calculations. Geochemical speciation calculations were carried out on pore water extracts from 0 month and 12 month-aged columns using the Pitzer database data0.ypf.R2 of EQ3/6 version 8.1 (22). The thermodynamic database was modified to include the formation of aqueous $\mathrm{Ca}_{2} \mathrm{UO}_{2}\left(\mathrm{CO}_{3}\right)_{3}(\mathrm{aq})$ and $\mathrm{CaUO}_{2}\left(\mathrm{CO}_{3}\right)_{3}{ }^{2-}$ species (23). The temperature dependence of the uranium-carbonate complex was added from the non-Pitzer version (data0.ymp.R5) (24). EQ3 was used to calculate the charge 
imbalance in the measured aqueous solutions. In most cases, a concentration of $\mathrm{NO}_{3}{ }^{-}$, which was not measured in the pore extracts, was assumed based on its concentration in the injection solution (measured). This appears reasonable given the conservative behavior of the nitrate ion in the system. In samples collected close to the plume front, however, $\mathrm{NO}_{3}^{-}$was adjusted rather than $\mathrm{Na}^{+}$, since the concentration of the nitrate is expected to approach zero at the front. EQ3 calculations were initially carried out at $25^{\circ} \mathrm{C}$ using the measured $\mathrm{pH}$ at this temperature. Subsequently, the temperature was adjusted upward to $70^{\circ} \mathrm{C}$ (the temperature of the experiments) using EQ6, without allowing any minerals to precipitate, and $\mathrm{pH}$ was then calculated based on charge balance at temperature.

\section{Results and Discussion}

Aging Effect on pH and Major Ion Composition of Plume Liquid Phase. The extracted plume liquids from individual segments of each column were analyzed (room temperature) for $\mathrm{pH}$ and major ion composition. The resulting profiles are presented in Figure 4 (only $\mathrm{pH}$ and $\mathrm{U}$ data are available for column 12 mon-2). To conceptualize the reaction process and facilitate comparisons with the field data, we normalized the column lengths to plume distances identified by the location of $\mathrm{pH}$ minima of each column, with plume front at 1.0, and displaced native pore water and plume body ahead and behind the plume front, respectively. Presented in Figures 4-pH' and 4-pH are $\mathrm{pH}$ profiles of all columns along actual and normalized distance, respectively, showing that variations over time are small. Normalized plume distances are used through the rest of this paper. Additionally, the measured $\mathrm{Na}, \mathrm{C}, \mathrm{P}$, and $\mathrm{S}$ were normalized to their influent 
concentrations in the original MWS for easier comparisons between initial and reacted concentrations. Because $\mathrm{Ca}$, and $\mathrm{Mg}$ were not contained in the influent MWS, but came solely from the sediment, their concentrations are given in $\mathrm{mM}$ units.

While the $\mathrm{pH}$ value of original MWS was 10.4 , and that of non-reacted pore water was 8.4, all columns showed a $\mathrm{pH}$ minimum at the plume front, with the lowest $\mathrm{pH} 6.4$, being four units lower than the $\mathrm{pH}$ of original MWS and two units lower than the $\mathrm{pH}$ of non-reacted pore water (Figure 4-pH'). The measured $\mathrm{pH}$ values varied from about 7 at the plume front to about 10 near the plume source. The $\mathrm{pH}$ values of displaced soil water (7.0 to 7.9 ) were lower than 8.4 , the $\mathrm{pH}$ of non-reacted pore water; apparently because of mixing of soil water with some acidic plume front liquid. The mechanism of plume $\mathrm{pH}$ evolution is attributed to displacement of exchangeable $\mathrm{Ca}^{2+}$ and $\mathrm{Mg}^{2+}$ from the sediment by the high $\mathrm{Na}^{+}$concentrations contained in the infiltrating MWS, then concentrating at the plume front upon the plume advancement, and with subsequent precipitation of $\mathrm{Ca}$ and $\mathrm{Mg}$ phases that drive $\mathrm{pH}$ reduction. The more detailed discussions on plume $\mathrm{pH}$ evolution can be found in our earlier papers (18-20). The new understanding gained from this study is that the $\mathrm{pH}$ zones formed upon MWS infiltration remained the same after aging. Thus, we predict $\mathrm{pH}$ values to vary from near 10 at the plume source to 7 around the plume front for an aged plume in the field. Importantly, the $\mathrm{pH}$ profile from the near tank borehole 299-E33-45 showed $\mathrm{pH}$ values between 9.5 to 7.4 (2) (Figure 2-pH), consistent with our prediction. In Figures 2 the elevated U concentrations (and other contaminants not shown) at the depths between 45 to $51 \mathrm{~m}$ indicate that the neutral $\mathrm{pH}$ zone is indeed a part of the plume. Our results provide the mechanistic explanation for the field observed near neutral $\mathrm{pH}$ at the leading edge of the alkaline plume. 

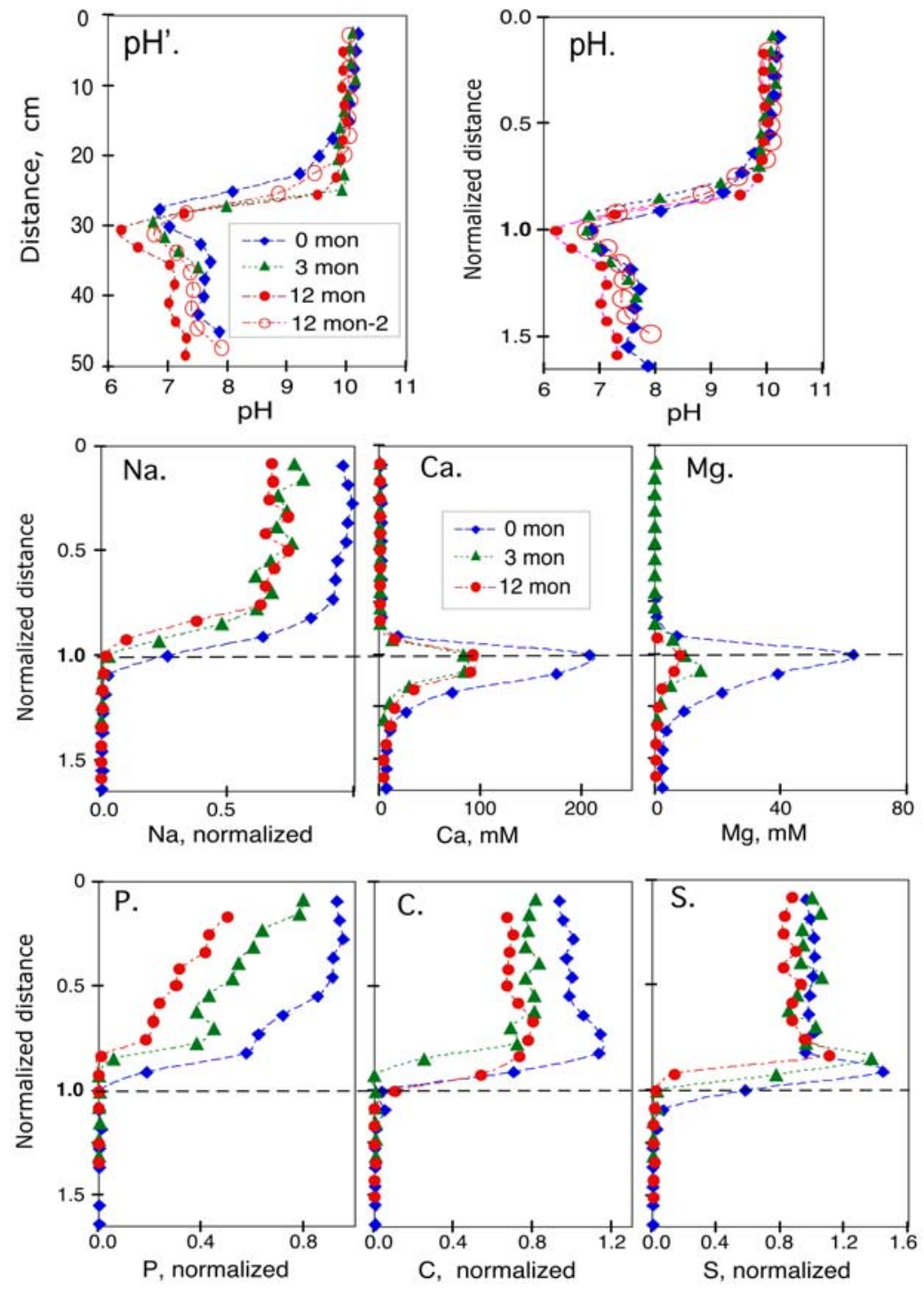

Figure 4. Measured $\mathrm{pH}$ and major ion concentrations along the flow path for plumes with different aging times. The figures - $\mathrm{pH}^{\prime}$ and $-\mathrm{pH}$ are measured $\mathrm{pH}$ profiles as actual column distances and as normalized distances, respectively (normalized to the plume length 1.0 with the plume front defined by the measured locations of $\mathrm{pH}$ minima). The measured $\mathrm{Na}, \mathrm{P}, \mathrm{C}$, and $\mathrm{S}$ concentrations were normalized to their influent concentrations (3.4, 0.34, 0.75, and $0.24 \mathrm{M}$, respectively) in the initial MWS. The initial MWS did not contain $\mathrm{Ca}$ and $\mathrm{Mg}$, and the sediment is their only source. 
Sodium is the dominant cation in plume liquid phase, with an influent concentration of 3.4 M. The normalized $\mathrm{Na}^{+}$profiles (Figures 4-Na) show steady state was approached within about 3 months. In the plume body $\sim 70 \%$ of the initial sodium remained in the solution phase and the concentration decreased in the proximity of the plume front. The tank waste solution did not contain $\mathrm{Ca}^{2+}$ and $\mathrm{Mg}^{2+}$. Cation exchange of $\mathrm{Na}^{+}$replacing exchangeable $\mathrm{Ca}^{2+}$ and $\mathrm{Mg}^{2+}$ from the sediment mineral surfaces produced sharp peaks of $\mathrm{Ca}^{2+}$ and $\mathrm{Mg}^{2+}$ concentrations at the plume fronts (Figures 4-Ca and 4$\mathrm{Mg}$ ). Before aging, $\mathrm{Ca}^{2+}$ concentrations were up to hundreds of $\mathrm{mM}$, and $\mathrm{Mg}^{2+}$ tens of $\mathrm{mM}$. The zones of elevated $\mathrm{Ca}^{2+}$ and $\mathrm{Mg}^{2+}$ concentrations beyond distance 1.0 reflect not only rapid cation exchange, but diffusion and hydrodynamic dispersion as well. Aging reduced $\mathrm{Ca}^{2+}$ and $\mathrm{Mg}^{2+}$ concentrations, but the $\mathrm{Ca}^{2+}$ and $\mathrm{Mg}^{2+}$ peaks remained with maximum values of $80 \mathrm{mM}$ and $10 \mathrm{mM}$ for $\mathrm{Ca}^{2+}$ and $\mathrm{Mg}^{2}$, Amazingly, elevated concentrations of $\mathrm{Ca}^{2+}$ and $\mathrm{Mg}^{2+}$ were found within the neutral $\mathrm{pH}$ region of the field plume, with peak values $60 \mathrm{mM}$ and $30 \mathrm{mM}$, respectively (Figure 2-Ca and 2-Mg). This consistency validated our conceptual model of $\mathrm{pH}$ zoning for saline-alkaline waste plumes.

The concentration profiles of major anions are normalized by the influent concentrations of $0.24 \mathrm{M} \mathrm{SO}_{4}{ }^{2-}, 0.34 \mathrm{M} \mathrm{HPO}_{4}{ }^{2-}$, and $0.75 \mathrm{M} \mathrm{CO}_{3}{ }^{2-}$ (less reactive $\mathrm{NO}_{3}{ }^{-}$ was not analyzed). Among the anions, aging had the least effect on $\mathrm{SO}_{4}{ }^{2-}$ concentrations. About $85 \%$ of original $\mathrm{SO}_{4}{ }^{2-}$ remained in the plume liquid phase after aging. The phosphate concentrations at plume fronts are practically zero, indicating precipitation and adsorption of P-containing solids before and during aging, and that steady state might not have reached for phosphate precipitation. Aging reduced $\mathrm{CO}_{3}{ }^{2-}$ concentrations in the pore 
waters. About $30 \%$ of the original $\mathrm{CO}_{3}{ }^{2-}$ precipitated during aging. Similar to phosphate, carbonate-containing minerals are among the major secondary solid phases. About $70 \%$ of the initial $\mathrm{CO}_{3}{ }^{2-}$ remained in the plume liquid, $0.5 \mathrm{M}$, at the steady state, which is consistent with the peak value measured in the field plume $(0.4 \mathrm{M})$ at the location of peak $\mathrm{U}$ concentration (Figure 2- $\mathrm{CO}_{3}{ }^{2-}$ ). As an important consequence, this stable high $\mathrm{CO}_{3}{ }^{2-}$ concentration in the plume liquid phase largely maintained the mobility of $U$.

U Partitioning Between Pore-Liquid and Sediment. We reported in our earlier paper (15) that the extent of $U$ retention by sediment is inversely correlated to flow rate of the waste streams at the time of initial spill. Although waste plume flow rates varied widely depending on sediment permeability distributions and waste source conditions in the field, we chose a relatively slow flow rate of pore water velocity $5 \mathrm{~cm}^{\text {day }}{ }^{-1}$, to obtain higher $U$ retention. Another important control of $U$ retention by the sediment is the extent of drainage (or saturation) of the waste liquid at the time of initial spilling. We chose saturated conditions for studying aging to approach the upper limit of sediment retention. Figures $5 \mathrm{a}$ and $5 \mathrm{~b}$ show independently measured U-concentration profiles of the pore liquid and sediment phases, respectively, and $U$ partitioning factors in 5c (ratios of solidassociated vs. liquid-associated $U$, not conventional $K_{d}$ ). Approximate steady state for $U$ concentrations was reached within 3 months. In Figure 5a, at aging time zero, normalized $U$ aqueous concentrations were about 0.95 in the plume body, and 1.1 at the plume front. The enriched $U(>1.0)$ at the plume front was due to formation and accumulation of U-containing colloids (15). Aging substantially decreased U liquid phase concentrations from 0.95 to 0.20 , and this difference is attributed to $\mathrm{U}$ precipitation and 
intragranular diffusion during aging. From the independently analyzed U-concentrations in sediment (Figure 5b), aging largely increased $U$ concentrations in sediments, from 0.01 increased to $8-11 \mathrm{mmol} \mathrm{kg}^{-1}$. The very low U-concentrations in non-aged sediments reflect the precipitation rate control on $\mathrm{U}$ retardation, partly related to intragranular diffusion. The effective partitioning factors in Figure $5 \mathrm{c}$ show very small values, about $2\left(\log _{10}\right)$, before aging. This is because the very high liquid phase U-concentration and insignificant $U$ precipitation within short times. Values of the partitioning factor increased to close to $0\left(\log _{10}\right)$ within the plume body after aging, mainly due to precipitation. Large values of partition factor, up to $+4\left(\log _{10}\right)$, are seen within the plume front (around the normalized distance $=1.0$ ). These high partition factors at the plume fronts are resulted from nearly completed $\mathrm{U}$ precipitation and sorption, which only occurred at the plume front upon aging (Figure 5a). The most significant finding of this work is that up to $20 \%$ of influent $\mathrm{U}(0.114 \mathrm{M}$ originally) remained in pore liquids at the steady state after aging. Continuous gravity-driven migration of the residual tank waste solution is likely responsible for the growing $\mathrm{U}$ concentrations detected 2006 from borehole 299-E33-18 (Figure 3). 


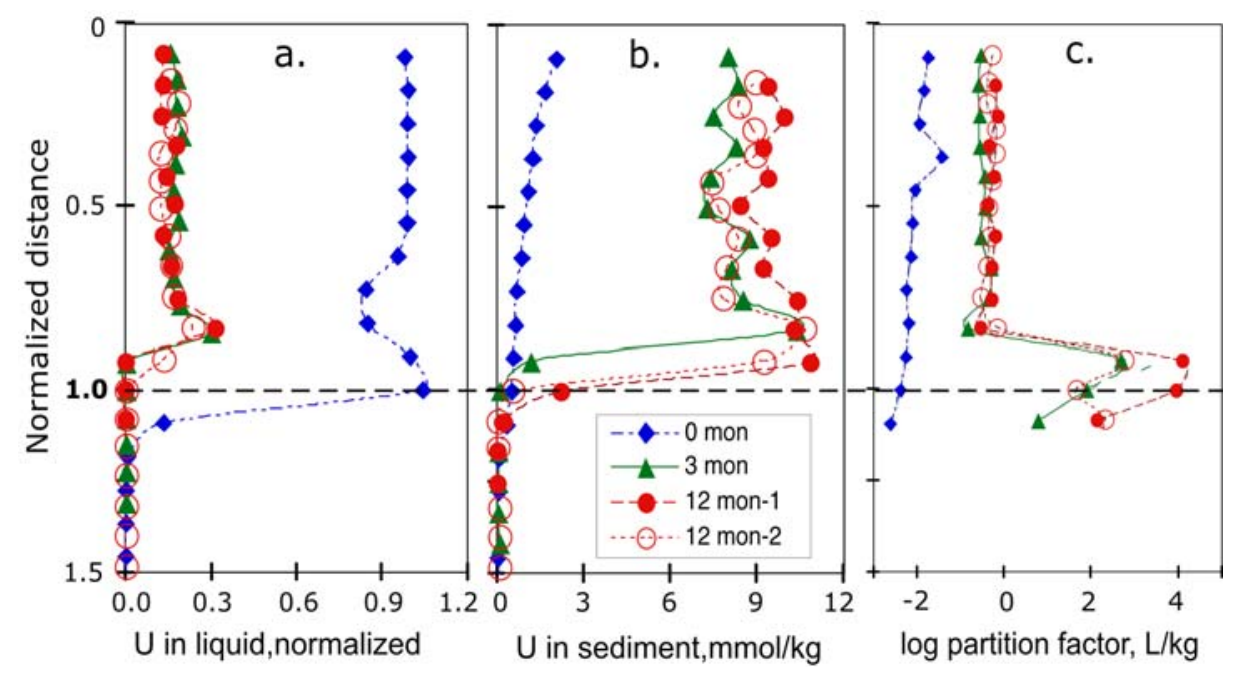

Figure 5. Aging effects on U partitioning between sediments and pore liquids. (a)

Profiles of normalized $U$ concentrations in pore liquids at different aging times. (b)

Profiles of $U$ concentrations in paired sediment solid phase as aging time. (c) $\log _{10}$ partition factors of $U$.

U Speciation After Aging. Speciation of $U$ in aqueous phase was determined using time-resolved laser fluorescence spectroscopy (TRLFS), and through thermodynamic calculations. Three liquid samples were analyzed using TRLFS: the original MWS and two plume body pore liquid extracts from the normalized locations 0.83 and 0.50 of column 12 month-1. Their $\mathrm{pH}$ values were 9.5 and 10.0 , normalized carbonate concentrations 0.73 , and 0.67 , and normalized [U] 0.31 (the peak $U$ ) and 0.17 , respectively. The uranyl tricarbonate complex $\left(\mathrm{UO}_{2}\right)\left(\mathrm{CO}_{3}\right)_{3}{ }^{4-}$ was identified as the dominant $U$ species in the initial MWS and the two plume body pore liquids. The measured fluorescence spectra are presented in Figure SI-1 in the SI. The TRLFS measurements at the plume front pore extracts were not obtained (samples were 
consumed by the time of this experiment). However, thermodynamic calculations based on the measured pore water chemical compositions indicate $\mathrm{Ca}_{2} \mathrm{UO}_{2}\left(\mathrm{CO}_{3}\right)_{3}$ and $\mathrm{CaUO}_{2}\left(\mathrm{CO}_{3}\right)_{3}{ }^{2-}$ as stable $\mathrm{U}$ aqueous species in the plume front region because of the elevated $\mathrm{Ca}^{2+}$ concentration and neutral $\mathrm{pH}$.

Solid state U characterization was obtained using SEM/EDS and synchrotronbased micro-XRD (Beamline 12.3.2, Advanced Light Source, Lawrence Berkeley National Laboratory). Three samples were selected from the normalized locations 0.92 , 0.83 , and 0.29 of column 12 month-1, with $\mathrm{pH}$ values $7.3,8.8$ and 10.0 , respectively. Their chemical compositions of the pore liquids in equilibrium with the sediments are presented in Table 1, along with the sediment $U$ concentrations. Thin sections $(100 \mu \mathrm{m}$ thick) were made from epoxy embedded sediment grains. Presented in Figure 6 are SEM backscattered electron images from samples at locations 0.83 and 0.29 (Table 1), with bright color indicating abundance of $U$ solid phase. Figures $6 A 1-2$ show a plagioclase feldspar grain coated by $U$ solid phase, identified as Zippeite, $\mathrm{K}_{4}\left(\mathrm{UO}_{2}\right)_{6}\left(\mathrm{SO}_{4}\right)_{3}(\mathrm{OH})_{10} \bullet 4\left(\mathrm{H}_{2} \mathrm{O}\right)$. The $\mu$-XRD patterns are presented in the SI, Figure SI-2. Uranium sulfate has not been reported in studies of field borehole sediments. The chemical analyses of pore liquids show maximum $\mathrm{SO}_{4}{ }^{2-}$ concentration at this location (normalized concentration 1.10, Table 1 and Figure 4-S). Figures 6B-1-2 show intragranular pores filled by secondary U-containing solids. Interestingly, the U speciation is distinctly different in different micro-scale locations of this sample. The coatings are most closely identified as cejkaite, $\mathrm{Na}_{4} \mathrm{UO}_{2}\left(\mathrm{CO}_{3}\right)_{3}$; and the nano-veins as Na-weeksite, $\mathrm{Na}_{2}\left[\mathrm{UO}_{2}\right]_{2}\left[\mathrm{Si}_{2} \mathrm{O}_{5}\right)_{3} \bullet 4 \mathrm{H}_{2} \mathrm{O}$. The formation mechanisms for these different species are probably variable. Cejkaite might have formed earlier by precipitation in the 
initial MWS. The formation of uranyl silicates were likely slower and controlled by chemistry of micropores resulting from MWS diffusion and mineral dissolution. Boltwoodite, $\mathrm{Na}\left(\mathrm{UO}_{2}\right)\left(\mathrm{SiO}_{3} \mathrm{OH}\right) \cdot 1.5 \mathrm{H}_{2} \mathrm{O}$, was found in the sediment of location 0.92, where $\mathrm{pH}$ was near neutral. Uranyl silicates were identified as the dominant U-bearing minerals from 299-E33-45 core sediments by others (9-13). In this study we have only analyzed a few samples. Combining with the thermodynamic calculations based on measured pore fluid compositions (next section) we obtained more comprehensive understanding on $\mathrm{U}$ solid phase speciation.

Table 1. Pore Liquid chemical composition in equilibrium with sediments and $U$ concentrations at three locations along the the plume flow path

\begin{tabular}{|c|c|c|c|c|c|c|c|c|c|c|}
\hline $\begin{array}{l}\text { Normalized }^{@} \\
\text { sample } \\
\text { locations }\end{array}$ & $\mathrm{pH}$ & $\begin{array}{l}{[\mathrm{U}] \text { in }} \\
\text { solution } \\
(\mathrm{mM})\end{array}$ & $\begin{array}{c}\text { U in } \\
\text { sediment } \\
(\mathrm{mmol} / \mathrm{kg})\end{array}$ & $\begin{array}{c}\mathrm{Na} \\
\left(\mathrm{Norm}^{*}\right)\end{array}$ & $\begin{array}{l}\mathrm{Ca} \\
(\mathrm{mM}\end{array}$ & $\underset{(\mathrm{mM})}{\mathrm{K}}$ & $\begin{array}{c}\mathrm{C} \\
\left(\mathrm{Norm}^{*}\right)\end{array}$ & $\begin{array}{c}\mathrm{P} \\
\left(\text { Norm*) }^{*}\right)\end{array}$ & $\begin{array}{c}\mathrm{S} \\
\left(\text { Norm}^{*}\right)\end{array}$ & $\begin{array}{l}\text { U minerals } \\
\text { identified }\end{array}$ \\
\hline 0.29 & 10.0 & 13.8 & 8.9 & 0.66 & 0.6 & 7.6 & 0.67 & 0.43 & 0.82 & $\begin{array}{c}\text { Cejkaite } \\
\& \\
\text { Weeksite }\end{array}$ \\
\hline 0.83 & 8.8 & 15.5 & 10.6 & 0.37 & 2.0 & 67.7 & 0.10 & 0.008 & 1.10 & Zippeite \\
\hline 0.92 & 7.3 & 0.02 & 9.2 & 0.10 & 52.4 & 75.5 & 0.002 & 0.0001 & 0.14 & Boltwoodite \\
\hline
\end{tabular}

(a) Sample locations are normalized using the position of $\mathrm{pH}$ minima (defined as the plume front $=1.0$, and source $=0$ ). ${ }^{*}$ These concentrations were normalized to their initial concentrations in the waste solution. 


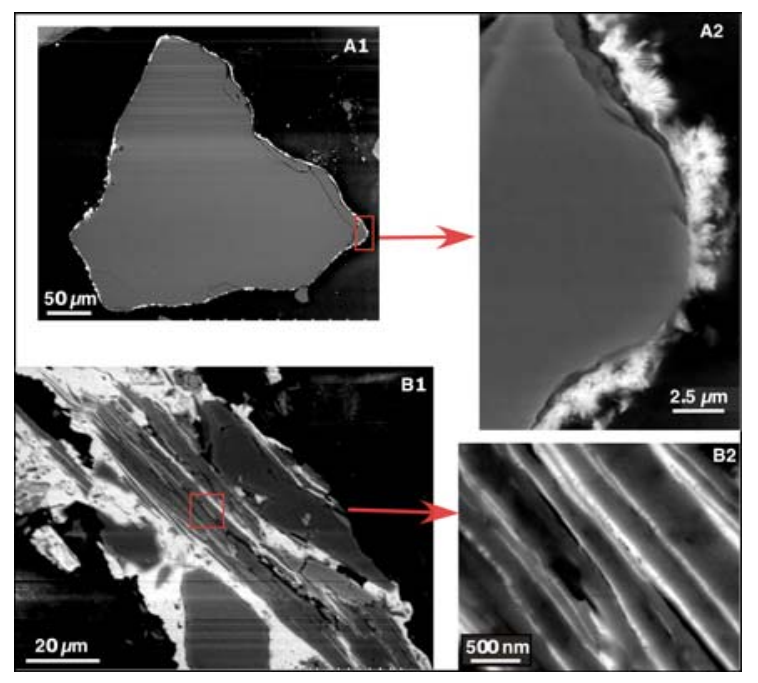

Figure 6. SEM backscattered electron images, with the lighter color indicating abundance of $U$ from sediment samples after one year of aging at $70^{\circ} \mathrm{C}$. (A) Plagioclase feldspar coated by zippeite. The sample was from normalized depth 0.83 (Table 1).

(B) Cejkaite was identified as the dominant U solid phase within plume body. However, weeksite, was found distinctly residing within the fine veins. The sediment sample was from normalized depth 0.29 .

Thermodynamic Calculations. The calculated aqueous speciation and mineral saturation states for the un-aged and aged column segments of selected locations along the depths of the column are provided in Table SI-1. The Pitzer-based calculations predict that most of the uranium in the pore fluids is complexed as $\mathrm{UO}_{2}\left(\mathrm{CO}_{3}\right)_{3}{ }^{4-}$ with significant amount $\mathrm{Ca}_{2} \mathrm{UO}_{2}\left(\mathrm{CO}_{3}\right)_{3}$ and $\mathrm{CaUO}_{2}\left(\mathrm{CO}_{3}\right)_{3}{ }^{2-}$ co-exist at the plume front. At the plume front (normalized depth $=1.0$ and $\mathrm{pH}=7.0$ ), $\mathrm{UO}_{2}\left(\mathrm{CO}_{3}\right)_{3}{ }^{4-}$ accounts for $35 \%$ and $\mathrm{CaUO}_{2}\left(\mathrm{CO}_{3}\right)_{3}{ }^{2-}+\mathrm{Ca}_{2} \mathrm{UO}_{2}\left(\mathrm{CO}_{3}\right)_{3} 40 \%$ of the total aqueous U. At the depth 0.9 (pH 8.0), these species proportions are $60 \%$ and $15 \%$, respectively. At depths $\leq 0.80$ and $\mathrm{pH}>9.0$, 
$99 \%$ of the aqueous $\mathrm{U}$ is as $\mathrm{UO}_{2}\left(\mathrm{CO}_{3}\right)_{3}^{4-}$. Aging reduced aqueous $\mathrm{U}$ by near $100 \%$ within the plume front region and $60-82 \%$ within the plume body mainly through precipitation. The calculations of mineral saturation indices states $\left(\log \mathrm{Q} / \mathrm{K}_{\text {eq }}\right)$ based on measured pore fluid compositions indicate that the mineral cejkaite was under-saturated at plume front, and slightly over saturated within the plume body before aging. This is consistent with the XRD results that cejkaite was one of the major U-bearing phases within the aged plume body. Before aging, boltwoodite was super-saturated in the entire plume. At the plume front, a large number of uranium-bearing phases were found to be supersaturated before aging, including zippeite, weeksite, $\left(\mathrm{UO}_{2}\right)_{3}\left(\mathrm{PO}_{4}\right)_{2}$, and schoepite. Calcite was also found to be close to saturation before aging. These predictions are consistent with the XRD measurements. Note that phosphate-bearing minerals were not identified in our $\mu$ XRD analyses, we believe that they must be associated with the sediments and this should be an area of future work.

Implications for Understanding Contaminant $U$ in the Hanford Vadose Zone. This laboratory simulation of the 1951 contamination event at the 200 Area Hanford Site has yielded several predictions on the plume scale behavior of contaminant $U$. The plume developed from infiltration of a saline and alkaline waste liquid has two distinct $\mathrm{pH}$ regions along a flow path: the plume body and plume front. The $\mathrm{pH}$ values within the plume body are alkaline (close to and lower than the source $\mathrm{pH}$ ), and around neutral within the plume front region. This $\mathrm{pH}$ difference produces vastly different $\mathrm{U}$ behavior, including $\mathrm{U}$ aqueous speciation, U-bearing minerals, and especially the aqueous $\mathrm{U}$ concentrations. Nearly complete U precipitation and sorption occurred within the plume 
front, yielding U partitioning factors (including adsorbed and precipitated) 4 orders of magnitude larger than in the plume body. The alkaline $\mathrm{pH}$ and high carbonate and sodium concentrations ensured the high stability of $\mathrm{UO}_{2}\left(\mathrm{CO}_{3}\right)_{3}{ }^{4-}$ in the pore liquids. Given the high saturated hydraulic conductivity of the Hanford formation sediment underlying the BX tank farm, infiltration rates of the waste solution during the spill event were likely fast. This initial fast percolation occurred with very little $U$ retention by the sediment because of the high $\mathrm{pH}$, high carbonate concentration, and short residence times. Depletion of the near-surface $U$ source, spreading of the contaminant plume, and diversions along lower permeability sediment lenses all contributed to slowing the plume's gravity-driven migration and eventual entry into the groundwater. The high $\mathrm{U}$ concentrations, large $\mathrm{pH}$ range within the plume, later stage long residence times, and long-term intragranular diffusion permit eventual formation of a complex set of U(VI) solid phases. The high carbonate concentration that persists in this plume keeps a significant fraction of the plume $\mathrm{U}$ in solution, permitting its continued entry into groundwater. 


\section{Acknowledgments}

This work was carried out under U.S. Department of Energy Contract No. DE-AC0376SF-00098. Funding was provided by the U.S. Department of Energy (DOE), Environmental Remediation Science Program (ERSP). We thank Joern Larsen (LBNL) for his technique support at the early stage of this research. The Advanced Light Source is supported by the Director, Office of Science, Office of Basic Energy Sciences, of the U.S. Department of Energy under Contract No. DE-AC02-05CH11231.

\section{Supporting Information Available}

Additional materials are available free of charge via the Internet at http://pubs.acs.org.

\section{References}

(1) McCain, R. G. Gamma and neutron Logs of 299-E33-18. DOE-EM/GJ13022006, Stoller Hanford Office, Richland, WA. 2006.

(2) Serne, R. J.; Last, G. V.; Gee, G. W.; Schaef, H. T.; Lanigan, D. C.;

Lindenmeier, C. W.; Lindberg, M. J.; Clayton, R. E.; Legore, V. L.; Orr, R. D.;

Kutnyakov, I. V.; Baum, S. R.; Geiszler, K. N.; Brown, C. F.; Valenta, M. M.;

Vickerman, T. S. Characterization of vadose zone sediment: Borehole 299-E33-45 near

BX-102 in the B-BX-BY waste management area. PNNL-14083; Pacific Northwest National Laboratory: Richland, WA 2002.

(3) Wang, Z.; Zachara, J. M.; Yantasee, W.; Gassman, P. L.; liu, C.; Joly, G.

Cryogenic laser induced fluorescence characterization of U(VI) in Hanford vadose zone pore waters. Environmental Science and Technology 2004, 38, 5591-5597. 
(4) Zachara, J. M.; Brown, C. F.; Christensen, J. N.; Davis, J. A.; Dresel, P. E.; Liu, C.; Kelly, S.; McKinley, J. P.; Serne, J.; Um, W. A Site-Wide Perspective on Uranium Geochemistry at the Hanford Site. Pacific Northwest National Laboratory, PNNL17031. 2007.

(5) Jones, T. E.; Simpson, B. C.; Wood, M. I.; Corbin, R. A. Preliminary inventory estimates for single-shell tank leaks in B, BX, and BY tank farms. CH2M Hill, Hanford Group. Inc.: Richland, WA 2001.

(6) Christensen, J. N.; Dresel, P. E.; Conrad, M. E.; Maher, K.; Depaolo, D. J. Identifying the sources of subsurface contamination at the Hanford Site in Washington using high-precision uranium isotopic measurements. Environmental Science and Technology 2004, 38, 3330-3337.

(7) Dresel, P. E.; Evans, J. C.; Farmer, O. T. Investigation of isotopic signatures for sources of groundwater contamination at the Hanford Site. PNNL-13763; Pacific Northwest National Laboratory: Richland, WA 2002.

(8) RPP-10098, Field Investigation Report for Waste Management Area B-BX-BY, Rev. 0, CH2M HILL Hanford Group, Inc., Richland, Washington. 2003.

(9) Catalano, J. G.; McKinley, J. P.; Zachara, J. M.; Heald, S. M.; Smith, S. C.;

Brown, G. E., Jr. Changes in uranium speciation through a depth sequence of contaminated Hanford sediments. Environmental Science and Technology 2006, 40, 2517-2524.

(10) Catalano, J. G.; Heald, S. M.; Zachara, J. M.; Brown, G. E., Jr. Spectroscopic and diffraction study of uranium speciation in contaminated vadose zone sediments from 
the Hanford Site, Washington state. Environmental Science and Technology 2004, 38, 2822-2828.

(11) McKinley, J. P.; Zachara, J. M.; Liu, C.; Heald, S. C.; Prenitzer, B. I.;

Kempshall, B. W. Microscale controls on the fate of contaminant uranium in the vadose zone, Hanford Site, Washington. Geochimica Cosmochimica Acta 2006, 70, 1873-1887.

(12) Wang, Z.; Zachara, J. M.; Gassman, P. L.; liu, C.; Qafoku, O.; Yantasee, W.;

Catalano, J. G. Fluoresecence spectroscopy of U(VI)-silicates and U(VI)-contaminated Hanford sediment. Geochimica Cosmochimica Acta 2005, 69, 1391-1403.

(13) McKinley, J. P.; Zachara, J. M.; Wan, J.; McCready, D. E.; Heald, S. M.

Geochemical controls on contaminant uranium in vadose Hanford formation sediments at the 200 Area and 300 Area, Hanford Site, Washington,. Vadose Zone J. 2007, 6:10041017.

(14) Liu, C.; Zachara, J. M.; Qafoku, O.; McKinley, J. P.; Heald, S. M.; Wang, Z.

Dissolution of uranyl microprecipitates in subsurface sediments at Hanford Site, USA. Geochimica Cosmochimica Acta 2004, 68, 4519-4537.

(15) Wan, J.; Tokunaga, T. K.; Kim, Y.; Wang, Z.; Lanzirotti, A.; Saiz, E.; Serne, J. R. Effect of saline waste solution infiltration rates on uranium retention and spatial distribution in Hanford sediments. Environmental Science and Technology 2008, 42, $1973-1978$.

(16) Corbin, R. A.; Simpson, B. C.; Anderson, M. J.; Danielson III, W. F.; Field, J. G.; Jones, T. E.; Kincaid, C. T. Hanford soil inventory model (SIM) Rev. 1. RPP-26744 Rev.0, CH2M HILL Hanford Group, Inc. , Richland, WA 2005. 


$$
\text { Serne, R. J.; Jones, T. E.; Lindberg, M. J.; Schaef, H. T.; K. M. Krupka, K. M. }
$$

Laboratory Scale Bismuth Phosphate Extraction Process Simulation To Track Fate of Fission Products. PNNL-14120, Pacific Northwest National Laboratory, Richland, WA 2003.

(18) Wan, J.; Larsen, J. T.; Tokunaga, T. K.; Zheng, Z. pH neutralization and zonation in alkaline-saline tank waste plumes. Environmental Science and Technology 2004, 38, 1321-1329.

(19) Wan, J.; Tokunaga, T. K.; Larsen, J. T.; Serne, R. J. Geochemical evolution of highly alkaline and saline tank waste plumes during seepage through vadose zone sediments. Geochimica Cosmochimica Acta 2004, 68, 491-502.

(20) Wan, J.; Tokunaga, T. K.; Saiz, E.; Larsen, J. T.; Zheng, Z. Colloid formation at waste plume fronts. Environmental Science and Technology 2004, 38, 6066-6073.

(21) Wang, Z.; Zachara, J. M.; Yantanssee, W.; Liu, C.; Gassman, P. L.; Joly, A. G. Cryogenic Laser Induced Fluorescence Characterization of U(VI) in Hanford Vadose Zone Pore Waters. Environ. Sci. Technol. 2004, 38, 5591-5597.

(22) Sandia National Laboratories, In-Drift Precipitates/Salts Model, Analysis Model Report ANL-EBS-MD-000045 (Rev.03), U.S. Department of Energy, Office of Civilian Radioactive Waste Management. Las Vegas, Nevada, 2007.

(23) Dong, W.; Brooks, S. C. Determination of the formation constants of ternary complexes of uranyl and carbonate with alkaline earth metals $(\mathrm{Mg} 2+, \mathrm{Ca} 2+, \mathrm{Sr} 2+$, and $\mathrm{Ba} 2+$ ) using anion exchange method. Environmental Science and Technology 2006, 40, $4689-4695$. 
(24) Sandia National Laboratories, Qualification of Thermodynamic Data for Geochemical Modeling of Mineral-Water Interactions in Dilute Systems, Analysis Model Report ANL-WIS-GS-000003 (Rev. 01), U.S. Department of Energy, Office of Civilian Radioactive Waste Management. Las Vegas, Nevada, 2007.

\section{Brief}

Laboratory simulations of a tank waste spill yielded new understanding on growing sizes and concentrations of uranium plumes at the Hanford Site. 